\title{
Development of edible films obtained from submicron emulsions based on whey protein concentrate, oil/beeswax and brea gum
}

\author{
Juan Pablo Cecchini ${ }^{1}$, María J Spotti ${ }^{1}$, Andrea M Piagentini ${ }^{1}$, \\ Viviana G Milt ${ }^{2}$ and Carlos R Carrara ${ }^{1}$
}

\begin{abstract}
Edible films with whey protein concentrate (WPC) with a lipid component, sunflower oil (O) or beeswax (W), to enhance barrier to water vapor were obtained. Brea gum was used as emulsifier and also as matrix component. In order to achieve emulsion with small and homogeneous droplet size, an ultrasonicator equipment was used after obtaining a pre-emulsion using a blender. The films were made by casting. Effects of lipid fraction on droplet size, zeta potential, mechanical properties, water vapor permeability (WVP), solubility, and optical properties were determined. The droplet size of emulsions with BG decreased when decreasing the lipid content in the formulation. The zeta potential was negative for all the formulations, since the $\mathrm{pH}$ was close to 6 for all of them and pl of BG is close to 2.5, and pl of B-lactoglobulin and $\alpha$-lactalbumin (main proteins in WPC) are 5.2 and 4.1, respectively. Increasing W or SO content in blended films reduced the tensile strength and puncture resistance significantly. BG and WPC films without lipid presented better mechanical properties. The presence of lipids decreased the WVP, as expected, and those films having BG improved this property. BG films were slightly amber as a result of the natural color of the gum. BG has shown to be a good polysaccharide for emulsifying the lipid fraction and improving the homogeneity and mechanical properties of the films with WPC and beeswax or oil.
\end{abstract}

\section{Keywords}

Brea gum, WPC, submicron emulsion, ultrasonic, edible film

Date received: 30 August 2016; accepted: 18 January 2017

\section{INTRODUCTION}

With the aim to improve the quality and safety of food products, edible films have been proposed as an alternative to petroleum-derived packaging (Acevedo-Fani et al., 2015). The effectiveness of edible coatings depends on their composition. Polysaccharides and proteins have been commonly used materials for producing edible film and coatings (Pereda et al., 2011).

Polysaccharides and proteins can be effective as gas barriers $\left(\mathrm{O}_{2}\right.$ and $\left.\mathrm{CO}_{2}\right)$ and they have overall suitable mechanical and optical properties but are highly

Food Science and Technology International 0(0) 1-11

(C) The Author(s) 2017 Reprints and permissions:

sagepub.co.uk/journalsPermissions.nav

DOI: $10.1177 / 1082013217695170$

journals.sagepub.com/home/fst

๑SAGE sensitive to moisture and exhibit poor water vapor barriers; meanwhile lipid components such as sunflower oil and beeswax, among others have low water vapor permeability (WVP) (Pérez-Gago and Krotcha, 2000).

Physical and mechanical properties of emulsion composite films are highly dependent on lipid content, lipid particle size, and viscoelasticity of the lipid.

${ }^{1}$ Instituto de Tecnología de los Alimentos, Universidad Nacional del Litoral, Argentina

${ }^{2}$ Facultad de Ingeniería Química, Universidad Nacional del Litoral, Argentina

Corresponding author:

Juan Pablo Cecchini, Instituto de Tecnología de los Alimentos, Universidad Nacional del Litoral, 1 de mayo 3250, (3000) Santa $\mathrm{Fe}$, Argentina.

Email: jpcecchini@gmail.com 
In emulsion-based films formed by nonpolar substances and water soluble polymeric solutions, phase separation can occur due to lack of stability of the emulsion (Otoni et al., 2014). Such phase separation is undesirable as it leads to nonhomogeneous films. One way of improving emulsion stability to aggregation and gravitational separation is by reducing droplet diameter (Leong et al., 2009). High-energy emulsification methods are recommendable because the droplet size distribution in the emulsion can be controlled and fine emulsions can be produced from a large variety of materials (Jafari et al., 2007). Ultrasound generators are capable of producing emulsions in the submicron range or form translucent nano-emulsions with average droplet sizes up to $40 \mathrm{~nm}$ (Kaltsa et al., 2013). Other strategy for decreasing the particle size is to choose a good emulsifier. Emulsifiers are surface-active molecules that readily adsorb at the oil-water interface, facilitate emulsion formation by lowering the interfacial tension, and form a protecting film (Guzey et al., 2004; Krstonošić et al., 2015; McClements, 2005). They also prevent droplet aggregation by generating repulsive forces between droplets (Wang et al., 2011). Stabilizers are used to provide long-term emulsion stability, some of them by adsorbing into the interface while others only modifying the viscosity of the continuous phase due to their nonadsorbing character. Brea gum (BG) has shown to be a good emulsifier because it is adsorbed in the oil/water interface and also it increases the viscosity of the systems (Castel et al., 2017).

Whey proteins are a co-product of the cheese making industry. Whey protein is usually commercialized as whey protein concentrate (WPC), containing between 25 and $80 \mathrm{~g} / 100 \mathrm{~g}$ of proteins, or as whey protein isolate, containing more than $80 \mathrm{~g} / 100 \mathrm{~g}$ of proteins. WPC is low cost and readily available.

Whey proteins have been used to obtain edible films and coatings, often with other biopolymers such as gelatin, alginate, mesquite gum, pullulan, beeswax, carnauba wax among others (Osés et al., 2009; Pérez-Gago and Krochta, 2000; Talens and Krotcha 2005).

Brea gum is defined as an acidic polysaccharide, composed of $75 \mathrm{~g} / 100 \mathrm{~g}$ of hydrolysable sugars, such as L-arabinose, D-xylose, D-glucuronic acid and 4-O-methyl-D-glucuronate (De Pinto et al., 1993), and it does not contain starch, dextrin, or tannins. These carbohydrates are in association with a small percentage of protein (about $8 \mathrm{~g} / 100 \mathrm{~g}$ ), which may indicate the presence of proteoglycans which are crucial in the gum functionality (Majewska-Sawka and Nothnagel 2000), mainly in emulsifying properties. The easy access to this inexpensive, nontoxic, hydrophilic, and biodegradable polysaccharide makes viable its potential use as film matrix for different applications.
BG could have a great economic, social, and environmental importance in Argentina and also in some countries of South America. BG has similar properties to others gums which Argentina imports, as Arabic gum (Castel et al., 2017). The study of the properties and potential uses of the gum can lead to its commercialization with significant profits for the country and the region. It could support the indigenous communities, and from an environmental point of view, this GB tree can be an important element to avoid desertification of land.

In a previous work, we have studied the use of this gum for emulsion-based films with different glycerol (Gly) and beeswax (W) content adding Tween 80 as an emulsifier. We have found that regardless the $\mathrm{W}$ concentration, films with $0 \mathrm{~g} / 100 \mathrm{~g}$ Gly were too brittle and they could not be handled and films with $40 \mathrm{~g} / 100 \mathrm{~g}$ Gly were too tacky and gummy, consequently they could not be unpeeled. Therefore, $20 \mathrm{~g} / 100 \mathrm{~g}$ was the satisfactory amount of plasticizer, and the films obtained had good mechanical properties and WVP values. In this work, our aim was to evaluate the incorporation of WPC to these films, and two different types of lipids: beeswax or sunflower oil, using only BG as emulsifier/stabilizer and ultrasonic treatment for obtaining submicron emulsions films.

\section{MATERIALS AND METHODS \\ Materials}

WPC-80 was purchased from Arla Food Ingredients S.A. (Buenos Aires, Argentina). BG was collected and supplied by a native community of Tartagal city (Salta, Argentina). The exudate of BG was collected from trees as solid drops. BG was grinded, dissolved in distilled water overnight, centrifuged $(15,000 \mathrm{~g}$ for $15 \mathrm{~min})$, and then filtrated by $0.5 \mu \mathrm{m}$ Microclar glass fiber filter. The concentration of the solution was determined by gravimetric method. The beeswax (W) and sunflower oil (O) were of commercial grade. Glycerol (Gly) was used as plasticizer and sodium azide was used as antimicrobial; both were of analytical grade and were provided from Cicarelli (Argentina).

\section{Film preparation}

WPC at $12 \mathrm{~g} / 100 \mathrm{~g}$ was pretreated at $68.5^{\circ} \mathrm{C}$ during $2 \mathrm{~h}$. This previous heat treatment improves the emulsifying properties of whey proteins by denaturation and exposure of hydrophobic groups. The concentration ratio of WPC:BG:Gly in the film forming solution was 6:3:2.68. Sodium azide at $0.2 \mathrm{~g} / 100 \mathrm{~g}$ was added to prevent microbial contamination. Two series of experiments were conducted varying the type of lipid (W or SO) and varying the lipid:BG ratio $(1: 1,1: 2$, and 1:3). 
Table 1. Composition of the film-forming solutions expressed in \% (w/w)

\begin{tabular}{llllll}
\hline Film notation & WPC & Gly & BG & Beeswax & $\begin{array}{l}\text { Sunflower } \\
\text { oil }\end{array}$ \\
\hline WPC-BG & 6 & 2.68 & 3 & - & - \\
WPC-BG-O1 & 6 & 2.68 & 3 & - & 1 \\
WPC-BG-01.5 & 6 & 2.68 & 3 & - & 1.5 \\
WPC-BG-O3 & 6 & 2.68 & 3 & - & 3 \\
WPC-O1.5 & 6 & 2.68 & - & - & 1.5 \\
WPC-BG-W1 & 6 & 2.68 & 3 & 1 & \\
WPC-BG-W1.5 & 6 & 2.68 & 3 & 1.5 & - \\
WPC-BG-W3 & 6 & 2.68 & 3 & 3 & - \\
WPC-W1.5 & 6 & 2.68 & - & 1.5 & - \\
\hline
\end{tabular}

Formulations prepared with W were called WPCBG-W1, WPC-BG-W1.5, and WPC-BG-W3 for 1, 1.5 , and $3 \mathrm{~g} / 100 \mathrm{~g}$ of $\mathrm{W}$, respectively, and films prepared with sunflower oil were called WPC-BG-O1, WPCBG-O1.5, and WPC-BG-O3 for $1,1.5$, and $3 \mathrm{~g} / 100 \mathrm{~g}$ of $\mathrm{SO}$, respectively. Also, films without lipids (WPC-BG) and films without BG were prepared. Those films made without BG were called WPC-O1.5 (with O) and WPC-W1.5 (with W) as can be seen in Table 1.

Film forming solutions were heated at $90^{\circ} \mathrm{C}$ for $30 \mathrm{~min}$ in a water bath, in order to melt the beeswax. Immediately after heat treatment, the pre-emulsions were obtained using a Waring Blender 8010EG (Waring Products, USA) for $4 \mathrm{~min}$ at high speed. In order to decrease the droplet size, these pre-emulsions were subject to ultrasound treatment (VibraCell VCX750-Y, USA) at $20 \mathrm{kHz}$ (frequency), $75 \%$ amplitude and $750 \mathrm{~W}$ (nominal power input) for $750 \mathrm{~s}$. Solutions were filtered with a sieve and were degassed by applying vacuum to remove dissolved air. After that, the exact amount of each system to reach $1 \mathrm{~g}$ of solid per plate was poured onto polyethylene Petri dishes. Films were dried at $40^{\circ} \mathrm{C}$ for $5 \mathrm{~h}$, and then, they were placed at room temperature for $12 \mathrm{~h}$. The dried films were conditioned in an environmental chamber set at $32{ }^{\circ} \mathrm{C}$ and $75.1 \%$ relative humidity ( $\mathrm{RH}$ ) for at least 3 days before characterization.

\section{Droplet size and zeta potential measurements}

Size distributions of emulsions droplets and zeta potential were determined using a dynamic light scattering particle size analyzer (Malvern Nanozetasizer ZS90, Westborough, MA) at $25^{\circ} \mathrm{C}$. Measurements of the diluted solutions were done at least in duplicate; the droplet diameter and Zeta potential were reported. Prior to the measurements were done, $\mathrm{pH}$ values were determined.

\section{Film thickness}

Film thickness was measured with a micrometer (Testing Machine, Inc., USA) at six random positions in each film. The measurement was carried out by quintuplicate for each formulation.

\section{Mechanical properties}

Experiments were made on an Instron Universal Testing Machine (Series 3340, Instron Corp., USA). The mechanical properties were evaluated by tensile and puncture tests. For each mechanical test, triplicate measurements were performed. In the puncture test, films of $8.5 \mathrm{~cm}$ of diameter were fixed to a support with a circular opening and crossed by a $2 \mathrm{~mm}$ diameter cylindrical probe moving at a constant speed of $0.8 \mathrm{~mm} / \mathrm{s}$. Force-deformation curves were recorded, in which maximum strength $(\mathrm{N})$ and maximum deformation $(\mathrm{mm})$ were determined at the rupture point.

To evaluate tensile properties, the films were cut into strips of $60 \mathrm{~mm} \times 7 \mathrm{~mm}$ (length $\times$ width). The samples were mounted between grips, in which the initial grip gap distance was $30 \mathrm{~mm}$. The crosshead speed was $0.05 \mathrm{~mm} / \mathrm{s}$. The parameters obtained from stress versus strain curves were: tensile strength (TS, MPa) calculated by dividing the maximum strength $(\mathrm{N})$ by the cross-sectional area (thickness of film $(\mathrm{mm}) \times$ strip wide $(7 \mathrm{~mm})$ ) and elongation $(\mathrm{E}, \%)$ calculated as the difference in length of specimen at the rupture point with respect to the original distance between the grips $(30 \mathrm{~mm}) \times 100$ (Han et al., 2006).

\section{WVP measurements}

The gravimetric method of ASTM E96-95 (2005) was used to determine WVP. Glass cups with cylindrical base of $4.5 \mathrm{~cm}$ diameter with a hole of $3 \mathrm{~cm}$ in diameter and $3 \mathrm{~cm}$ in depth were used with $4 \mathrm{~g}$ of totally dried ( $4 \mathrm{~h}$ at $200{ }^{\circ} \mathrm{C}$ ) $\mathrm{CaCl}_{2}$ beads (Anedra) put. Films were placed between the cup and an o-ring, to seal the sample to the glass. After that, the cups were placed in constant RH chamber at $32{ }^{\circ} \mathrm{C}$ and $75.1 \% \mathrm{RH}$. The initial weight of the cups and the weight every $24 \mathrm{~h}$ was recorded. Weight gain of test cups was recorded until $\mathrm{CaCl}_{2}$ was visible wet. These values were used to calculate WVP. Determinations were performed at least in triplicate. WVP of films was calculated as follows

$$
\mathrm{WVP}=\mathrm{W} \times \mathrm{e} /(\mathrm{A} \times \mathrm{t} \times \Delta \mathrm{P})
$$

where $\mathrm{w}$ is the weight gain of the cup (g) at time $\mathrm{t}(\mathrm{s})$; defined as $w=$ mcup $_{t}-$ mcup $_{\text {to }}$; where mcup $_{\text {to }}$ is the weight of the cup at time zero and mcup $_{t}$ is the weight of the cup at time of the experience; e is the film thickness (m); A is the exposed area of film $\left(\mathrm{m}^{2}\right)$, 
which in this case was $1.13411 \times 10^{-3} \mathrm{~m}^{2} ; \Delta \mathrm{P}$ is the vapor pressure difference across the film $(\mathrm{Pa})$, where $\Delta \mathrm{P}$ is $4759.6 \mathrm{~Pa}$, defined as the difference between the pressure of saturated water vapor outside the cup at $32^{\circ} \mathrm{C}$ and $0.751 \mathrm{RH}$ and inside the cup at $32^{\circ} \mathrm{C}$ and $0.0 \mathrm{RH}$.

\section{Water solubility}

The modified methodology described by Wang et al. (2007) was used. Film samples were cut into $2.5 \mathrm{~cm}$ circles in diameter and dried at $70^{\circ} \mathrm{C}$ for $24 \mathrm{~h}$ until constant weight. The samples were immersed in $100 \mathrm{~mL}$ of distilled water for $24 \mathrm{~h}$ at $32^{\circ} \mathrm{C}$. Finally, the samples were removed from the water, filtered with a $0.5 \mu \mathrm{m}$ paper filter, and dried at $70^{\circ} \mathrm{C}$ for $24 \mathrm{~h}$ to obtain a constant weight. Determinations were performed in triplicate. Water solubility ( $\%$ ) was obtained by following equation

$$
\begin{aligned}
& \text { Water solubility }(\mathrm{WS} \%) \\
& =(\text { initial weight }- \text { final weight }) \\
& \quad / \text { initial weight } \times 100
\end{aligned}
$$

\section{Optical properties}

Transparency. Film transparency was estimated by using ASTM D1746-97 (2000) method, with a spectrophotometer Jenway 7305 (Staffordshire, UK). Film samples were cut into rectangular strips and were placed into the spectrophotometer cell. The transparency of the films was calculated according to Han and Floros (1997) by the following equation

$$
\text { Transparency }=\left(\log \% \mathrm{~T}_{600}\right) / \mathrm{e}
$$

where $\mathrm{T}_{600}$ is the transmittance (\%) at $600 \mathrm{~nm}$ and $\mathrm{e}$ is the thickness of the film ( $\mathrm{mm})$.

Color and opacity. Film color and opacity were measured with a colorimeter (Minolta $508 \mathrm{~d} / 8$, Konica Minolta Sensing Inc., Osaka, Japan) using an illuminant D65 and observer angle of $10^{\circ}$. Measurements were performed onto a white background on both sides of the films at least on six different locations per sample (three on each side). The following parameters: $\mathrm{L}^{*}, \mathrm{a}^{*}$, and $b^{*}$ were evaluated.

Opacity was calculated according to Spotti et al. (2012) applying equation (4) (Acevedo-Fani et al., 2015).

$$
\text { Opacity }=\mathrm{L}_{\mathrm{b}}^{*} / \mathrm{L}_{\mathrm{w}}^{*} \times 100
$$

where $\mathrm{L}_{\mathrm{b}}^{*}$ and $\mathrm{L}_{\mathrm{w}}^{*}$ are $\mathrm{L}^{*}$ parameters measured on the black and white background, respectively.

\section{Scanning electron microscopy}

Microstructure was examined by scanning electron microscopy (SEM Phenom World ProX, USA) using an accelerating voltage of $10 \mathrm{kV}$. The samples were cut into small pieces, and then were left under vacuum during 1 day prior to be mounted on stubs. The magnification used was $580 \times$ on the film surface and $1400 \times$ on the cross-section.

\section{Statistical analysis}

Mean values and their corresponding standard error were calculated. For statistical treatment of data, StatGraphics Centurion XV software was used, and analyses of variance (ANOVA) were done. When statistical differences were found, LSD's test $(\alpha=0.05)$ was carried out. If data could not meet ANOVA assumptions, nonparametric analysis of variance (KruskallWallis) was performed, and box and whisker plot was used to determine which median are significantly different from other (not shown). Graphic presentations were performed using OriginPro 8 software (OriginLab Corporation, Northampton, USA).

\section{RESULTS AND DISCUSSION \\ Droplet size and zeta potential measurements}

The droplet sizes of the emulsions are shown in Table 2. WPC-W1.5 and WPC-O1.5, which do not have $\mathrm{BG}$, had lower droplet size than those emulsions having BG: WPC-BG-W1.5 and WPC-W1.5, droplet sizes are 182.4 and 55.9, and for WPC-BG-O1.5 and WPC-O1.5 values are 508.5 and 52.7, respectively. The BG presence highly increased the particle size. This could be attributed to the complex macromolecular structure of the $\mathrm{BG}$, characterized by a heterogeneous chemical composition system with a broad molecular weight distribution. According to Castel et al. (2016), the gum is formed by three different fractions: the bulk of the gum (approx. $84 \%$ of the polysaccharides) is a polysaccharide of $2.79 \times 10^{3} \mathrm{~g} / \mathrm{mol}$; the second major fraction (approx. 16\% of the polysaccharides) is a polysaccharide-protein complex with a molecular mass of $1.92 \times 10^{5} \mathrm{~g} / \mathrm{mol}$; and the third fraction consisted of protein species with a wide range of molecular weights. Some of the proteins are forming aggregates through disulfide bridges in native conditions with molecular weight ranging from 6.5 to $66 \mathrm{kDa}$.

For those formulations with WPC-BG and oil, the droplet size of emulsions decreased when lipid content 
Table 2. Droplet diameters, polydispersity index (Pdl), $\mathrm{pH}$, and $\zeta$-potential values of emulsions

\begin{tabular}{lclll}
\hline Film forming solution & Droplet diameter $(\mathrm{nm})$ & Pdl & $\mathrm{pH}$ & $\zeta$-potential $(\mathrm{mV})$ \\
\hline WPC-BG & $310.1 \pm 23.6 \mathrm{c}$ & $0.187 \pm 0.121$ & 6.14 & $-29.30 \pm 0.78 \mathrm{ab}$ \\
WPC-BG-O1 & $368.2 \pm 47.3 \mathrm{e}$ & $0.198 \pm 0.015$ & 6.12 & $-29.67 \pm 0.80 \mathrm{ab}$ \\
WPC-BG-O1.5 & $508.5 \pm 12.6 \mathrm{~d}$ & $0.136 \pm 0.032$ & 6.12 & $-31.88 \pm 0.52 \mathrm{c}$ \\
WPC-BG-O3 & $625.1 \pm 36.2 \mathrm{f}$ & $0.100 \pm 0.057$ & 6.03 & $-29.18 \pm 1.06 \mathrm{ab}$ \\
WPC-O1.5 & $52.7 \pm 4.2 \mathrm{a}$ & $0.354 \pm 0.007$ & 6.71 & $-29.07 \pm 0.54 \mathrm{~b}$ \\
WPC-BG-W1 & $211.1 \pm 33.5 \mathrm{~b}$ & $0.184 \pm 0.107$ & 6.03 & $-31.85 \pm 1.03 \mathrm{c}$ \\
WPC-BG-W1.5 & $182.4 \pm 40.5 \mathrm{~b}$ & $0.270 \pm 0.043$ & 5.9 & $-31.06 \pm 1.34 \mathrm{bc}$ \\
WPC-BG-W3 & $670.6 \pm 2.8 \mathrm{f}$ & $0.094 \pm 0.033$ & 5.68 & $-31.83 \pm 0.54 \mathrm{c}$ \\
WPC-W1.5 & $55.9 \pm 4.5 \mathrm{a}$ & $0.347 \pm 0.005$ & 6.37 & $-28.38 \pm 1.30 \mathrm{~b}$ \\
\hline
\end{tabular}

Note: Values were given as mean \pm standard deviations. $a, b, c, d, e, f$ Mean values with same superscript within a column are not significantly different $(p<0.05)$.

Table 3. Mechanical properties of the films

\begin{tabular}{llllc}
\hline Sample film & Thicknesses $(\mathrm{mm})$ & Puncture strength $(\mathrm{N} / \mathrm{mm})$ & Tensile strength $(\mathrm{MPa})$ & Elongation $(\%)$ \\
\hline WPC-BG & $0.208 \pm 0.009 \mathrm{c}$ & $15.65 \pm 1.21 \mathrm{c}$ & $1.23 \pm 0.23 \mathrm{~d}$ & $11.81 \pm 1.26 \mathrm{~d}$ \\
WPC-BG-O1 & $0.175 \pm 0.019 \mathrm{a}$ & $11.69 \pm 1.28 \mathrm{ab}$ & $0.73 \pm 0.12 \mathrm{c}$ & $8.83 \pm 3.12 \mathrm{c}$ \\
WPC-BG-O1.5 & $0.153 \pm 0.018 \mathrm{~b}$ & $12.36 \pm 3.07 \mathrm{~b}$ & $0.56 \pm 0.10 \mathrm{bc}$ & $5.68 \pm 0.79 \mathrm{ab}$ \\
WPC-BG-O3 & $0.159 \pm 0.016 \mathrm{ab}$ & $13.83 \pm 1.83 \mathrm{bc}$ & $0.45 \pm 0.03 \mathrm{ab}$ & $5.20 \pm 0.50 \mathrm{ab}$ \\
WPC-BG-W1 & $0.170 \pm 0.013 \mathrm{ab}$ & $15.78 \pm 2.64 \mathrm{c}$ & $1.05 \pm 0.48 \mathrm{~cd}$ & $7.55 \pm 1.94 \mathrm{bc}$ \\
WPC-BG-W1.5 & $0.173 \pm 0.015 \mathrm{a}$ & $11.28 \pm 2.49 \mathrm{ab}$ & $0.34 \pm 0.11 \mathrm{a}$ & $4.07 \pm 1.13 \mathrm{a}$ \\
WPC-W1.5 & $0.153 \pm 0.004 \mathrm{~b}$ & $9.54 \pm 0.83 \mathrm{a}$ & $0.63 \pm 0.23 \mathrm{c}$ & $7.82 \pm 2.11 \mathrm{c}$ \\
\hline
\end{tabular}

Note: Data corresponds to mean values and standard deviations. Values with different letters in each column are significantly different $(p<0.05)$.

in the formulation decrease. Emulsions prepared with 1 and $1.5 \mathrm{~g} / 100 \mathrm{~g}$ of wax showed lower droplet size than those obtained with the same concentration of oil. No differences were found in formulations with wax or oil at the highest concentration of lipids $(3 \mathrm{~g} / 100 \mathrm{~g})$.

All emulsions had low polydispersity index (PdI) values (data not shown), indicating a monomodal and narrow droplet size distribution. This is attributable to the high energy input of ultrasonication, leading to narrow particle size distribution (Jafari et al., 2007; Kaltsa et al., 2013). Moreover, the PdI values of those emulsions with $\mathrm{BG}$ were much lower than the emulsions without $\mathrm{BG}$, indicating that $\mathrm{BG}$ forms more uniform emulsions.

Regarding the zeta potential, all the formulations showed negative values (Table 2). WPC have $52 \%$ of $\beta-\lg$ and $20 \%$ of $\alpha$-la, which have pI of 5.2 and 4.1 , respectively (Dickinson, 1998). The zeta potential of $\mathrm{BG}$ was measured in a wide range of $\mathrm{pH}$, being always negative up to $\mathrm{pH}$ close to 2.5 . Therefore, in the $\mathrm{pH}$ of these emulsions, both macromolecules, WPC and BG, have negative charge. The $\mathrm{pH}$ of the solutions slightly decreased when wax was present.

\section{Films thicknesses}

Table 3 shows the thicknesses of all formulations except WPC-O1.5 and WPC-BG-W3, which could not be peeled off correctly. Probably in the case of WPCO1.5 films, even though the emulsion had very small particle size, the emulsion was not stable during the drying process since superficial oil could be seen on top of these films. This result would indicate that WPC alone is not a good emulsifier for this type of formulation, and the presence of $\mathrm{BG}$ would be a requirement for maintaining the stability of the emulsion during drying. In the case of WPC-BG-W3, this formulation presented discontinuities in the matrix, probably due to the high wax concentration. Thicknesses values are similar for all formulations in a range of $0.153-0.208 \mathrm{~mm}$. These values are similar to those found by Spotti et al. (2016) working with BG and wax, adding the same amount of solids per 
plate; they obtained thicknesses between 0.159 and $0.163 \mathrm{~mm}$.

\section{Mechanical properties}

Mechanical properties of the films are shown in Table 3. Films with BG showed higher puncture strength (PS) values $(11.29-15.78 \mathrm{~N} / \mathrm{mm})$ than the only formulation without BG: WPC-W1.5 $(9.54 \mathrm{~N} / \mathrm{mm})$.

All films with lipid (W or O) had lower PS values than the formulation without lipids. Films with WPC and BG and without lipids showed a high value for PS, similar to the formulation with $1 \mathrm{~g} / 100 \mathrm{~g}$ of wax (WPC-BG-W1).

In the case of films with wax, the increase in wax concentration from 1 to $1.5 \mathrm{~g} / 100 \mathrm{~g}$ decreased PS from 15.78 to 11.28 , being this difference statistically significant. These results are in agreement with Soazo et al. (2011), who studied films of WPC and wax. In that study, the parameters gradually decrease with the increase of wax content. According to the authors, the cause of decreasing in this parameter is due to a disruption in the biopolymer continuous matrix, inducing a heterogeneous film structure. In contrast, the samples with oil presented a tendency to increase the PS values with increasing in oil concentration, although the differences were not statistically significant.

TS and $\mathrm{E}$ values were in the ranges $0.34-1.23 \mathrm{MPa}$ and $4.07-11.81 \%$, respectively. The values obtained for E are similar with those found by Bertuzzi and Slavutsky (2013), who worked with films of BG and montmorillonite.

Films with only WPC and BG had the highest value of TS and $\mathrm{E}$. The incorporation of either oil or wax significantly decreased the TS and E values; both the quantity of lipid and the type of lipid had a significant effect on these mechanical properties. Similar results were found in literature for tensile test of whey protein emulsion films prepared with different lipids (Navarro-Tarazaga et al., 2008; Talens and Krotcha, 2005). The result suggested that the incorporation of lipids produced films with a higher heterogeneity, decreasing the values in these parameters (Bertuzzi et al., 2012). According to Spotti et al. (2016), a pronounced decrease in TS values can be seen when wax is present in films of BG, from $7.58 \mathrm{MPa}$ for films without lipids to $1.64 \mathrm{MPa}$ for films with $20 \%$ of wax. They found that E values decreased drastically with the addition of wax, from $8.22 \%$ to $4.85 \%$ for films without wax and with $20 \%$ of wax, respectively. Comparing these films with ours, TS values are higher but $\mathrm{E}$ is similar, indicating that the presence of WPC could generate more brittle films.

\section{Water vapor permeability}

Figure 1 shows the WVP of films. As can be observed, the presence of oil decreased the WVP from $9.5 \times 10^{-11}$ for WPC-BG-O1 to $5 \times 10^{-11} \mathrm{~g} /(\mathrm{m} \mathrm{s} \mathrm{Pa})$ for WPC-BGO3. The addition of wax had a similar behavior, decreasing the WVP from $10.5 \times 10^{-11}$ for WPC-BG$\mathrm{W} 1$ to $7.5 \times 10^{-11} \mathrm{~g} /(\mathrm{m} \mathrm{s}$ Pa) for WPC-BG-W1.5, being this difference statistically significant. There were no significant differences between films with wax and oil. Adding $1.5 \mathrm{~g} / 100 \mathrm{~g}(11.38 \mathrm{~g} / 100 \mathrm{~g}$ in dry basis) of wax (WPC-BG-W1.5) or oil (WPC-BG-O1.5) was enough to reduce the WVP $30 \%$ and $40 \%$, respectively, compared to those films without lipid (WPC-BG). These values are consistent with those obtained by Spotti et al. (2016) with BG-based films; the addition of $20 \mathrm{~g} / 100 \mathrm{~g}$ wax in dry basis reduced to a half the permeability values compared to those films without lipid (4.5 to $2 \times 10^{-11} \mathrm{~g} /(\mathrm{m} \mathrm{s} \mathrm{Pa})$. Slavutsky and Bertuzzi (2015) also studied films with BG and BG-montmorillonite, and obtained values in the range of 3.64 to $8.16 \times 10^{-10} \mathrm{~g} /(\mathrm{m} \mathrm{s} \mathrm{Pa})$; these films did not contain any lipid fraction showing that WVP is higher when all hydrophilic compound are present. Other studies with similar polysaccharides also showed similar trend: Osés et al. (2009) obtained WVP values between 5.6 and $5.9 \times 10^{-10} \mathrm{~g} /(\mathrm{m} \mathrm{s} \mathrm{Pa})$ in films with WPI and mesquite gum. Bravin et al. (2006) studied films of starch and methylcellulose, having a decrement in WVP from 20.50 to $11.68 \times 10^{-11} \mathrm{~g} /(\mathrm{m} \mathrm{s} \mathrm{Pa})$ when $20 \mathrm{~g} / 100 \mathrm{~g}$ of soybean oil was added. Min et al. (2009) also evaluated WPI-beeswax composite films and obtained similar results, from $2.46 \times 10^{-10}$ to $3.95 \times 10^{-10} \mathrm{~g} /(\mathrm{m} \mathrm{s} \mathrm{Pa})$, at ratios of WPI:W from $1: 1$ and $1: 0.5$, respectively.

\section{Solubility}

Solubility in water is an important property that must be taken into account for the film application; in some cases, it may require water insolubility to promote product integrity and water resistance, and in other total solubility could be needed (Bravin et al., 2006). As can be seen in Figure 2, all films with BG were partially soluble (solubility values ranging 46-58\%), and all of them could maintain their integrity during immersion, indicating quite high stability in the film network. It was observed that when lipid concentration increased, the solubility slightly decreased. BG contributes to a higher solubility, comparing all formulations with $\mathrm{BG}$ with that one without $\mathrm{BG}$, probably because of its hydrophilic nature. WPC-W1.5 had the lowest solubility $(25 \%)$, being similar to those obtained by Soazo et al. (2011), ranging from $13.6 \%$ to $34.4 \%$. 
Cecchini et al.

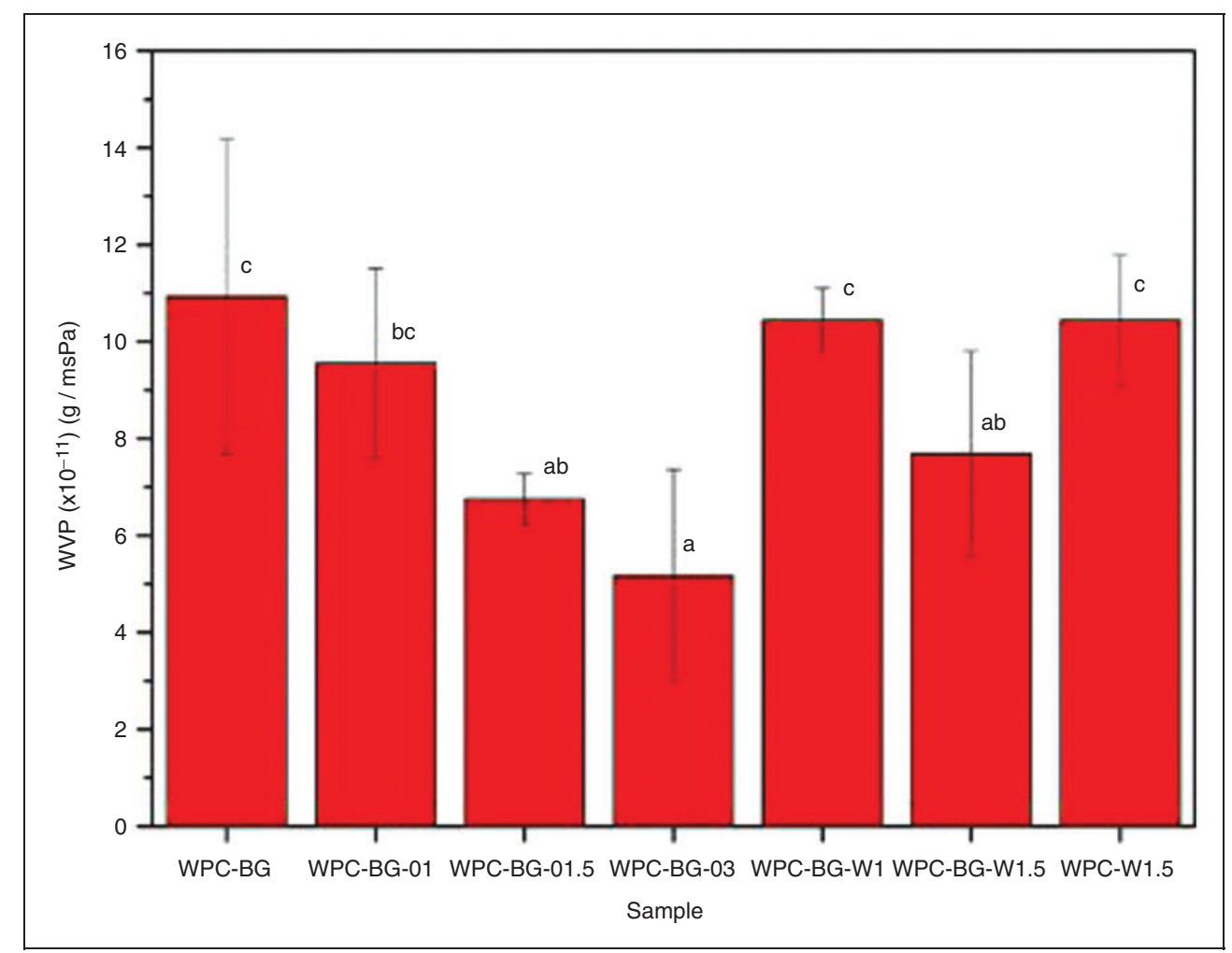

Figure 1. Water vapor permeability (WVP). Values with the same letters did not show significant differences, when LSD test was applied with $\alpha=0.05$.

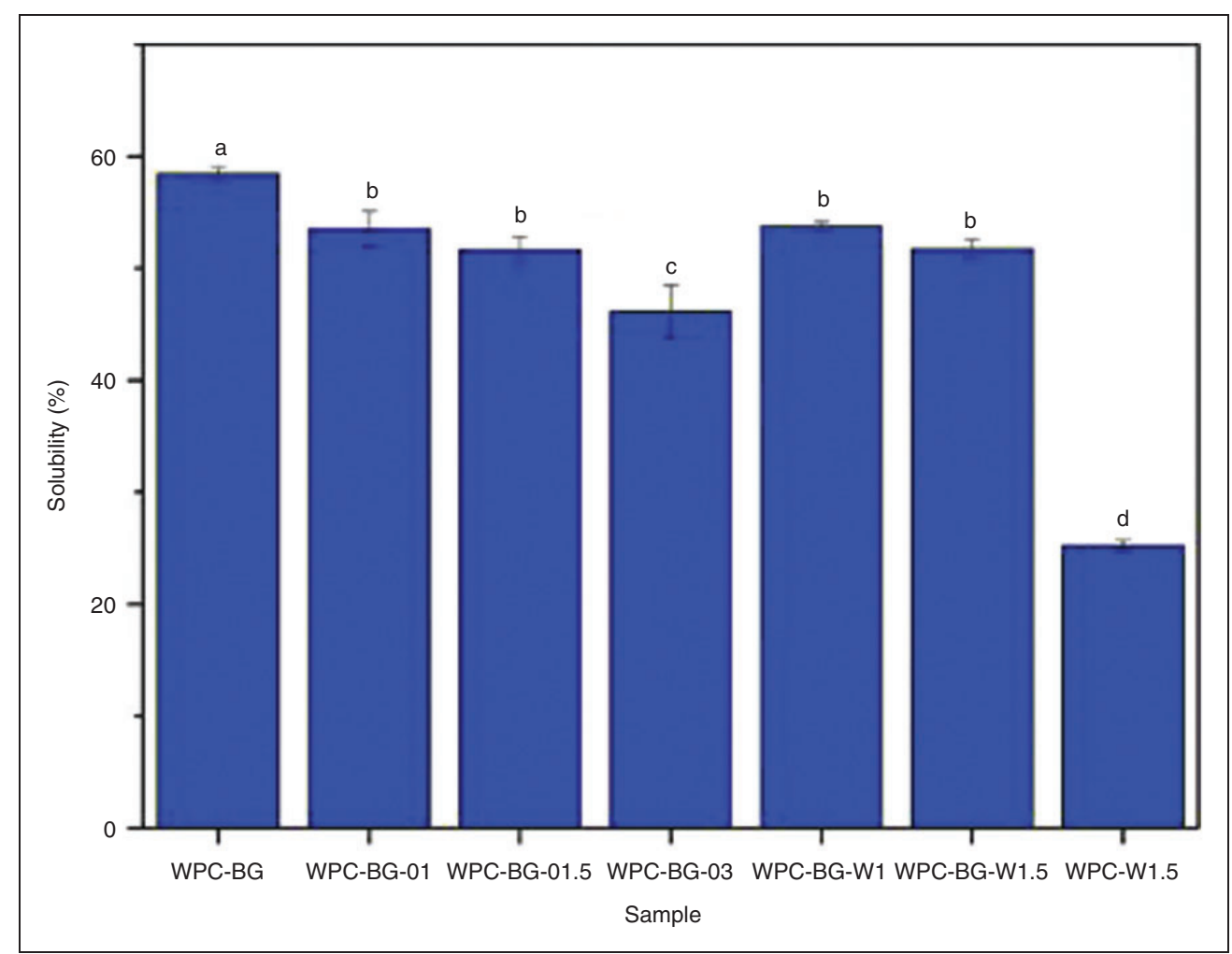

Figure 2. Solubility percent of films in water. Bars with different letters are significantly different at $p<0.05$. Error bar shows standard deviation. 
Table 4. Optical properties of films

\begin{tabular}{lcllll}
\hline \multirow{2}{*}{ Sample } & \multicolumn{2}{l}{ Color } & & & \\
\cline { 3 - 5 } & Transparency & $L^{*}$ & $a^{*}$ & $b^{*}$ & Opacity (\%) \\
\hline WPC-BG & $6.03 \pm 0.21 \mathrm{~b}$ & $77.21 \pm 1.41 \mathrm{~b}$ & $11.24 \pm 1.29 \mathrm{c}$ & $53.98 \pm 2.77 \mathrm{ab}$ & $51.28 \pm 2.24 \mathrm{~b}$ \\
WPC-BG-O1 & $7.23 \pm 0.42 \mathrm{~d}$ & $76.50 \pm 2.88 \mathrm{abc}$ & $12.20 \pm 2.43 \mathrm{bc}$ & $51.24 \pm 4.41 \mathrm{~b}$ & $55.57 \pm 0.33 \mathrm{c}$ \\
WPC-BG-O1.5 & $6.73 \pm 0.43 \mathrm{~cd}$ & $82.46 \pm 1.28 \mathrm{~d}$ & $6.84 \pm 1.24 \mathrm{~d}$ & $45.35 \pm 3.45 \mathrm{c}$ & $53.09 \pm 0.68 \mathrm{bc}$ \\
WPC-BG-O3 & $3.32 \pm 0.18 \mathrm{a}$ & $73.31 \pm 2.20 \mathrm{a}$ & $16.75 \pm 2.11 \mathrm{a}$ & $56.24 \pm 2.39 \mathrm{a}$ & $65.34 \pm 0.08 \mathrm{~d}$ \\
WPC-BG-W1 & $6.75 \pm 0.60 \mathrm{~cd}$ & $79.52 \pm 2.27 \mathrm{c}$ & $10.12 \pm 2.10 \mathrm{c}$ & $47.69 \pm 4.38 \mathrm{c}$ & $53.45 \pm 0.61 \mathrm{bc}$ \\
WPC-BG-W1.5 & $6.48 \pm 0.27 \mathrm{bc}$ & $74.85 \pm 2.04 \mathrm{ab}$ & $13.76 \pm 1.91 \mathrm{ab}$ & $54.96 \pm 3.2 \mathrm{a}$ & $52.0 \pm 0.88 \mathrm{~b}$ \\
WPC-W1.5 & $13.85 \pm 0.46 \mathrm{e}$ & $90.35 \pm 0.42 \mathrm{e}$ & $-1 \pm 0.04 \mathrm{e}$ & $13.44 \pm 1.27 \mathrm{~d}$ & $39.1 \pm 2.32 \mathrm{a}$ \\
\hline
\end{tabular}

Note: The films were stored at room temperature during 20 days. Values with different letters are significantly different at $p<0.05$.

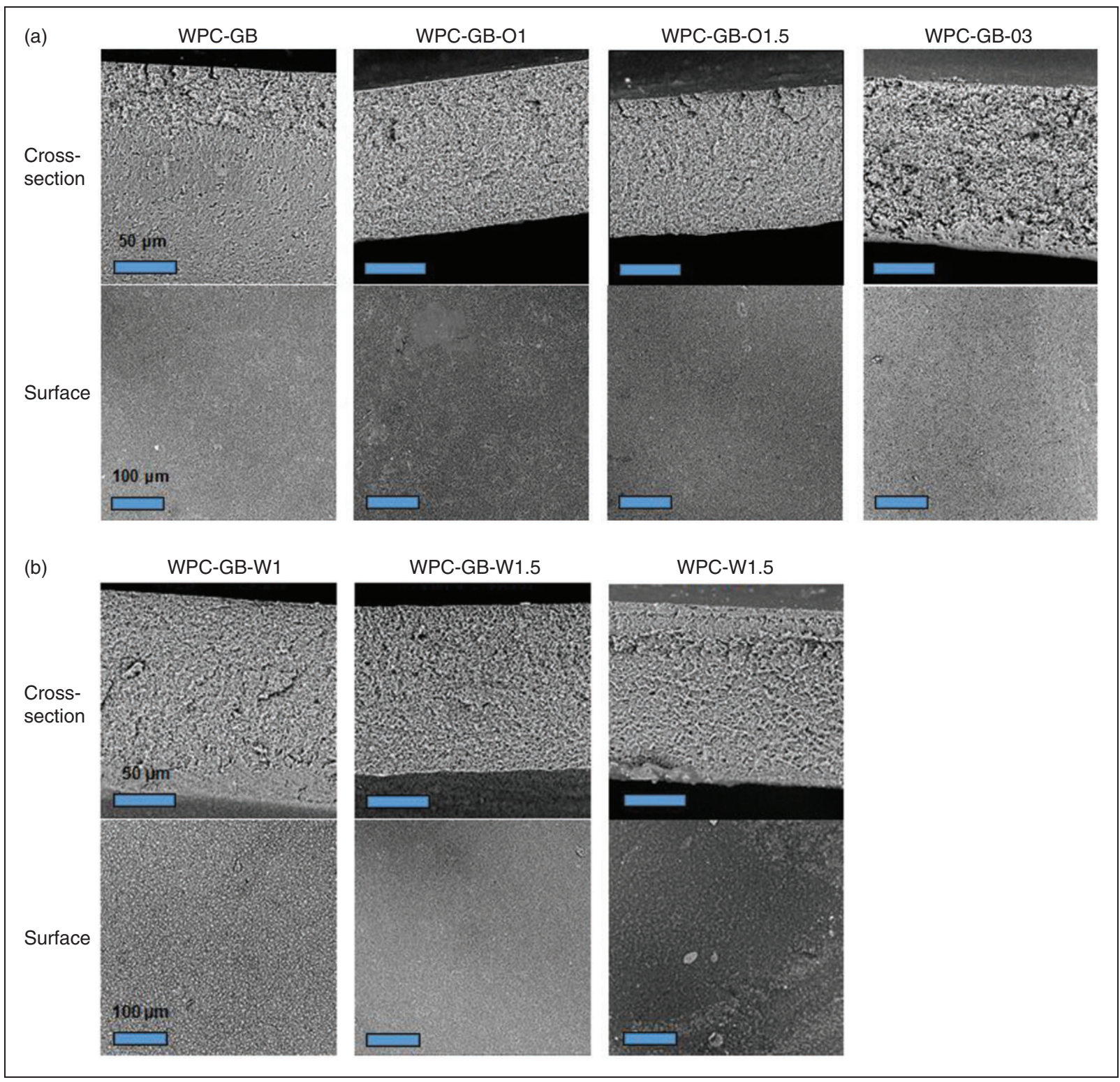

Figure 3. Scanning electron micrographs of submicron emulsion films: in the cross-section pictures the evaporation surface of the film is on the top. The surface micrographs showed the surface in contact with the air during drying. Films were observed at an intensity of $10 \mathrm{kV}$ and magnification of $580 \times$ (surfaces) or $1400 \times$ (cross-sections). 


\section{Optical properties}

Transparency. Transparency values are shown in Table 4. WPC-W1.5 films (without BG) had the higher value of transparency, being clearer and more transparent than other films. For films with BG, the transparency values were in the range 6-7.25\% $\mathrm{T} / \mathrm{mm}$, except for WPC-BG-O3 that had the lowest value, probably because is the measured formulation with the highest content of lipids. Similar values were reported by Han and Floros (1997), who obtained $5-10 \% \mathrm{~T} / \mathrm{mm}$ for low-density polyethylene films with $1 \mathrm{~g} / 100 \mathrm{~g}$ of potassium sorbate.

An increase in sunflower oil concentration resulted in a significant decrease of the transparency probably due to a higher lipid droplet size in the emulsion which obstructs the transmission of light (Sothornvit et al., 2010).

The incorporation of BG resulted in a loss of light transmittance, because of the gum confers brown color to the films. Higher values of transparency were obtained by Spotti et al. (2016) in films with BG and $0 ; 20$ and $40 \%$ of beeswax (concentrations in dry basis); these values were $10.29 ; 9.48$ and $7.95 \% \mathrm{~T} / \mathrm{mm}$, respectively, probably because these films were made only with BG without whey protein.

Color and opacity. The color of a film may influence the acceptability of a product, so it is important to evaluate the color and to consider its influence in the type of food packaging in which the films will be involved.

Color parameters of different films are shown in Table 4. All films (except for WPC-W1.5, the only formulation without $\mathrm{BG}$ ) presented positive $b^{*}$ values, which indicate yellow contribution, and positive $\mathrm{a}^{*}$ values, which indicate reddish color. According to the results, the incorporation of $\mathrm{BG}$ produced an increase in red and yellow color, conferring a soft brown appearance. Similar trends were obtained by Osés et al. (2009) in films with WPI and mesquite gum. They concluded that increment of gum content in films decreased the $\mathrm{L}^{*}$ and increased $\mathrm{a}^{*}$ and $\mathrm{b}^{*}$ values. Just as with color, the incorporation of BG increased the opacity of the films.

\section{Scanning electron microscopy}

SEM images of surface and cross-sectional areas of films are shown in Figure 3. Cross-section pictures showed that all the samples had a homogeneous and continuous structure. None of the samples has exhibited creaming or coalescence, although in some lipid droplets could be seen embedded in a continuous matrix. WPC-BG films were the most uniform samples, which had a denser structure with fewer amounts of voids. WPC-W1.5 films had more heterogeneous and rough appearance than the others with $\mathrm{BG}$. No major differences on the film surface were observed between formulations with wax or oil. No differences were found in the different sides of the films.

\section{CONCLUSIONS}

Composite films with WPC, BG and a lipid, beeswax (B) or sunflower oil (O), could be obtained. The application of ultrasound to emulsions generated submicron lipid droplet sizes, this leads to obtain compact films, with good visual aspect, homogeneous appearance, and good mechanical and water barrier properties. There was good interaction between WPC and BG, since films with both compounds had the best values of mechanical properties. The addition of lipids decreased all these parameters but enhanced water barrier properties. Films with BG had good appearance, were flexible, were easy to handle and had amber color. The color of these kinds of films could have application in bakery products or in products where the light brown color does not interfere in the perception of the food.

BG has shown to be totally compatible with WPC and beeswax or oil, so it can be used for improving the homogeneity and mechanical properties of the films. Therefore, this inexpensive and natural source material could be used as a film component.

\section{HIGHLIGHTS}

- The application of a natural sparingly exploited polysaccharide, brea gum (BG), in the development of edible films was studied.

- Films were obtained from emulsions of whey protein concentrate (WPC) and beeswax or sunflower oil, using the BG as natural emulsifier.

- Submicron emulsions made by ultrasound produce compact and homogeneous films.

- BG was a good emulsifier and produced homogeneous films, as examined by microscopy, with good mechanical properties.

\section{DECLARATION OF CONFLICTING INTERESTS}

The author(s) declared no potential conflicts of interest with respect to the research, authorship, and/or publication of this article.

\section{FUNDING}

The author(s) disclosed receipt of the following financial support for the research, authorship, and/or publication of this article: The authors are grateful for the financial support of projects: PICT-2011-1118: "Extensive use of non-wood forest products: purification, characterization and applications of 
Brea Gum and Espina Corona Gum," and CAI + D. UNL. 50120110100021 LI: "Utilization of a native polysaccharide for protection of lipophilic compounds." We also want to acknowledge the support of The National Council of Scientific and Technical Research.

\section{REFERENCES}

Acevedo-Fani A, Salvia-Trujillo L, Rojas-Graü $\mathrm{M}$ and Martín-Belloso O. (2015). Edible films from essential-oilloaded nanoemulsions: Physicochemical characterization and antimicrobial properties. Food Hydrocolloids 47: $168-177$.

ASTM (2000). Standard Test Method for Transparency of Plastic Sheeting. D1746-97. Philadelphia, PA: American Society for Testing and Materials.

ASTM (2005). Standard Test Methods for Water Vapor Transmission of Materials. E 96/E 96M. Philadelphia, PA: American Society for Testing and Materials.

Bertuzzi M and Slavutsky A. (2013). Formulation and characterization of film based on gum exudates from brea tree (Cercidium praecox). Journal of Food Science and Engineering 3: 113-122.

Bertuzzi M, Slavutsky A and Armada M. (2012). Physicochemical characterization of the hydrocolloid from Brea tree (Cercidium praecox). International Journal of Food Science and Technology 47: 768-775.

Bravin B, Peressini D and Sensidoni A. (2006). Development and application of polysaccharide-lipid edible coating to extend shelf-life of dry bakery products. Journal of Food Engineering 76: 280-290.

Castel V, Rubiolo A and Carrara C. (2017). Droplet size distribution, rheological behavior and stability of corn oil emulsions stabilized by a novel hydrocolloid (brea gum) compared with gum Arabic. Food Hydrocolloids 63: $170-177$.

Castel V, Zivanovic S, Jurat-Fuentes J, Santiago L, Rubiolo A, Carrara C, et al. (2016). Chromatographic fractionation and molecular mass characterization of Cercidium praecox (brea) gum. Journal of the Science of Food and Agriculture 96(13): 4345-4350.

De Pinto G, Rodriguez O, Martinez M and Rivas M. (1993). Composition of Cercidium praecox gum exudates. Biochemistry Systematic and Ecology 2: 297-300.

Dickinson E. (1998). Stability and rheological implications of electrostatic milk protein-polysaccharide interactions. Trends in Food Science and Technology 9: 347-354.

Guzey D, Kim HJ and McClements DJ. (2004). Factors influencing the production of $\mathrm{o} / \mathrm{w}$ emulsions stabilized by $\beta$ lactoglobulin-pectin membranes. Food Hydrocolloids 18: 967-975.

Han J and Floros J. (1997). Casting antimicrobial packaging films and measuring their physical properties and antimicrobial activity. Journal of Plastic Film and Sheeting 13: 287-298.

Han J, Seo G, Park L, Kim G and Lee D. (2006). Physical and mechanical properties of pea starch edible films containing beeswax emulsions. Journal of Food Science 71: 290-296.
Jafari S, He Y and Bhandari B. (2007). Production of submicron emulsions by ultrasound and microfluidization techniques. Journal of Food Engineering 82: 478-488.

Kaltsa O, Michon C, Yanniotis S and Mandala I. (2013). Ultrasonic energy input influence on the production of sub-micron $\mathrm{o} / \mathrm{w}$ emulsions containing whey protein and common stabilizers. Ultrasonics Sonochemistry 20: 881-891.

Krstonošić V, Dokić L, Nikolić I and Milanović M. (2015). Influence of xanthan gum on oil-in-water emulsion characteristics stabilized by OSA starch. Food Hydrocolloids 45: 9-17.

Leong T, Wooster T, Kentish S and Ashokkumar M. (2009). Minimising oil droplet size using ultrasonic emulsification. Ultrasonics Sonochemistry 16: 721-727.

Majewska-Sawka A and Nothnagel E. (2000). The multiple role of arabinogalactan proteins in plant development. Plant Physiology 122: 3-9.

McClements DJ. (2005). Food Emulsions: Principles, Practice, and Techniques, 2nd ed. Boca Ratón, FL: CRC Press.

Min S, Janjarasskul T and Krochta J. (2009). Tensile and moisture barrier properties of whey protein-beeswax layered composite films. Journal of the Science of Food and Agriculture 89: 251-257.

Navarro-Tarazaga $\mathrm{M}$, Sothornvit $\mathrm{R}$ and Pérez-Gago $\mathrm{M}$. (2008). Effect of plasticizer type and amount on hydroxypropil methylcellulose-beeswax edible film properties and postharvest quality of coated plums (cv. Angeleno). Journal of Agricultural and Food Chemistry 56: 9502-9509.

Osés J, Fabregat-Vázquez M, Pedroza-Islas R, Tomás S, Cruz-Orea A and Maté J. (2009). Development and characterization of composite edible films based on whey protein isolate and mesquite gum. Journal of Food Engineering 92: 56-62.

Otoni C, Pontes S, Medeiros E and Soares N. (2014). Edible films from methylcellulose and nanoemulsions of clove bud (Syzygium aromaticum) and Oregano (Origanum vulgare) essential oils as shelf life extenders for sliced bread. Journal of Agricultural and Food Chemistry 62: 5214-5219.

Pereda M, Ponce A, Marcovich N, Ruseckaite R and Martucci J. (2011). Chitosan-gelatin composites and bilayer films with potential antimicrobial activity. Food Hydrocolloids 25: 1372-1381.

Pérez-Gago M and Krochta J. (2000). Drying temperature effect on water vapor permeability and mechanical properties of whey protein-lipid emulsion films. Journal of Agricultural Food Chemistry 48: 2687-2692.

Slavutsky AM and Bertuzzi MA. (2015). Thermodynamic study of water sorption and water barrier properties of nanocomposite films based on brea gum. Applied Clay Science 108: 144-148.

Soazo M, Rubiolo A and Verdini R. (2011). Effect of drying temperature and beeswax content on physical properties of whey protein emulsion films. Food Hydrocolloids 25: 1251-1255.

Spotti MJ, Santiago L, Rubiolo A and Carrara CR. (2012). Mechanical and microstructural properties of milk whey protein/espina corona gum mixed gels. LWT-Food Science and Technology 48: 69-74. 
Spotti ML, Spotti MJ, Cecchini JP and Carrara CR. (2016). Brea gum (from Cercidium praecox) as a structural support of emulsion based films. LWT-Food Science Technology 68: 127-134.

Sothornvit R, Hong S, An D and Rhim J. (2010). Effect of clay content on the physical and antimicrobial properties of whey protein isolate/organo-clay composite films. LWT-Food Science Technology 43: 279-284.

Talens P and Krotcha J. (2005). Plasticizing effects of beeswax and carnauba wax on tensile and water vapor permeability properties of whey protein films. Journal of Food Science 70: 239-243.
Wang L, Liu L, Holmes J, Kerry J and Kerry J. (2007). Assessment of film-forming potential and properties of protein and polysaccharide-based biopolymer films. International Journal of Food Science and Technology 42: 1128-1138.

Wang B, Wang L, Li D, Adhikari B and Shi J. (2011). Effect of gum Arabic on stability of oil-in-water emulsion stabilized by flaxseed and soybean protein. Carbohydrate Polymers 86: 343-351. 